\title{
Damage by insect pests to the Djingarey Ber Mosque in Timbuktu: detection and control
}

\begin{abstract}
The Djingarey Ber Mosque in Timbuktu (Mali) is one of the most significant earthen construction in West Africa. Originally constructed in 1327, it was included in 1988 on the World Heritage UNESCO List for its unique architecture and historical importance. During its restoration, recently undertaken by the Aga Khan Trust for Culture, the wooden parts of the roof and architraves showed clear signs of threatening insect presence. In order to identify the pests responsible of the damage, evaluate its extent and suggest a proper control strategy, a detailed survey was performed inside the Mosque complex and in its immediate surroundings. The entomological inspection, performed in the dry-cold season, allowed to detect signs of insect damage in most of the wooden elements, even in the recently replaced beams, but also in walls, pillars and the precious decorated panels. Damages in the wood elements could be attributed to Amitermes evuncifer Silvestri (Termitidae), Bostrychoplites zycheli Marseuli (Bostrichidae) and Lyctus africanus Lesne (Lyctidae), which were collected alive on site. Injures in the walls and decorated panels appeared to be performed by hymenopterans such as "plasterer bees" (Colletidae) and Sphecidae. From the evaluation of the type and extent of damage in relation to the architecture and materials used in its construction and decoration, the most serious pest and the worse threat for the mosque is represented by termites. Control and preventive measures, in the view of a sustainable, long-lasting integrated management are suggested.
\end{abstract}

Key words: Bostrichidae, earthen construction, entomological survey, termites, xylophagous pests.

\section{INTRODUCTION}

Known to be constructed in 1327 at the initiative of the King Hadj Moussa upon his return from pilgrimage to Mekka, the Djingarey Ber Mosque is one of the most significant earthen construction in West Africa and the main congregational mosque of Timbuktu. In 1988, the site was included in the World Heritage UNESCO List for its unique architecture and historical importance. Not only the mosque has experienced a number of modifications but the organic nature of earthen architecture and its vulnerability to weathering elements makes it subject to rapid changes and alterations. Archaeological test pits, carried out in the main prayer hall, showed that at least 3 successive buildings have occupied the site. On the other hand, the main earthen ornaments on the qebbla 
wall and some pillars may date back from the $16^{\text {th }}$ century.

The Mosque, as it stands today, includes a large covered prayer hall supported by 25 rows of massive square pillars lined up in the direction east-west. This is where the imam preaches and the community gathers for Friday prayers. On top of the flat roof, the square minaret (14 $\mathrm{m}$ height) is the most significant urban feature, visible from distance. Both the minaret and the external walls of the mosque complex have "torons", typical elements of this architecture, consisting in beams of Marula wood (Sclerocarya birrea (Hochst.), Anacardiaceae) partially inserted in the walls and jutting out of them. The eastern wall, including a niche, the mihrab, providing direction to Mekka for the worship, is the oldest part of the mosque, which later developed to the West and North. Two courtyards are part of the precinct: the big sandy western courtyard is an open air extension of the prayer hall designed to accommodate the large number of community members for Friday prayers, while the northern courtyard is a more intimate one, separating the women praying area from the main praying hall. There are no foundations: the mosque is directly built on the sand with alhore stone blocks, a kind of tuff stone quarried in the nearby desert; the irregular stone blocks are assembled with mud mortar, the whole is then sealed with three layers of mud and straw plaster. The ceiling (about $460 \mathrm{~cm}$ height) is made of circular Doum palm (Hyphaene thebaica (L.) Mart., Arecaceae) beams (320 cm length, $20 \mathrm{~cm} \varnothing)$ covered with panels of "golettes", small wooden sticks ( $45 \mathrm{~cm}$ length, $2.5 \mathrm{~cm} \varnothing$ ) obtained from local shrub wood (Boscia angustifolia Guill. and Perr., Capparidaceae and Salvadora persica Wall., Salvadoraceae), to support the various mud layers of water tightness. The architraves between the pillars are made of Doum palm beams (220 m length, $20 \mathrm{~cm} \varnothing)$; the 14 entrances have doors of Marula wood. There are no windows, light and ventilation are provided by round holes on the roof, covered by special terracotta elements.

Between 2008 and 2010, the Aga Khan Trust for Culture (AKTC), the cultural agency of the Aga Khan Development Network, undertook the restoration of the whole site. Before restoration work commenced, the mosque was in poor condition: the roof was overloaded with hundreds of tons of accumulated mud and sand, creating damages on the carpentry palm tree beams and supportive pillars. Moreover, the inappropriate slopes design of the roof created water ingress compromising the wall's consistency and involving cavities. During the works, worrying signs of insect damage were discovered in the palm beams forming the roof and architraves. In order to evaluate the type and extent of the damage and to guarantee a proper and safe management of the problem, the AKTC recognized the need of a professional entomologist to perform a thorough inspection of the mosque and its immediate surroundings. The present work shows the results of the entomological survey and provides suggestions for a sustainable integrated management strategy of the insect pests in the Djingarey Ber Mosque.

\section{MATHERIALS AND METHODS}

The entomological survey was performed on January 6-12, 2009 in the city of Timbuktu (Mali) during the cold-dry season. At that time, the mosque was in an inter- 
mediate phase of the restoration project, with areas already fully restored, areas under restoration (roof removed, walls with removed external layers) and areas to be restored (Fig. 1). Accurate monitoring of all different parts and structures of the mosque complex and its surroundings was performed by looking carefully for any type of signs of insect presence and for alive/dead insects or insect parts.

Some of the wooden poles (wood of Eucalyptus sp.) inside the western courtyard were

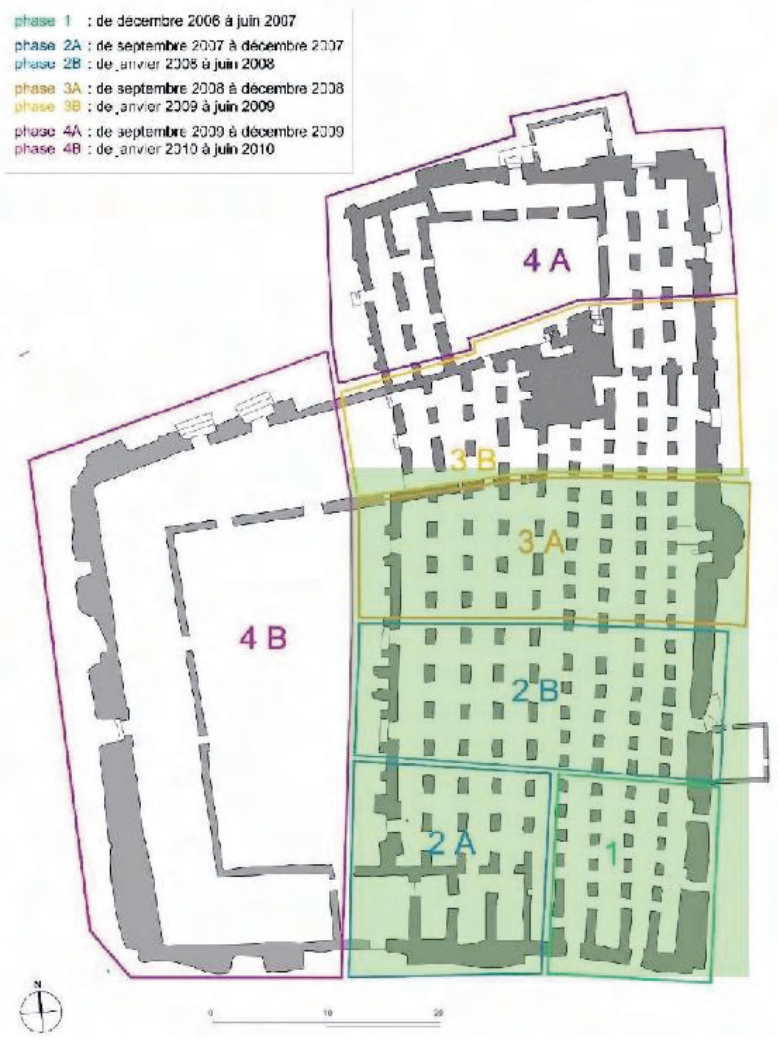

Fig. 1 - Map of the Djingarey Ber Mosque. At the time of the entomological survey, areas 1-2A$2 \mathrm{~B}$ were already restored, areas $3 \mathrm{~A}-3 \mathrm{~B}$ were under restoration, and areas $4 \mathrm{~A}-4 \mathrm{~B}$ not yet restored. 
extracted from the sand, opened, and alive insects were detected and collected. The survey was performed also in the mosque surroundings, that include: a) the external perimeter of the mosque complex and the streets leading to it, where heaps of old beams were found all over; b) the storage area, with piles of new and old beams and golettes, some of which were opened to collect alive insects; c) private houses in front of the mosque.

Observations were recorded and many pictures were taken by means of a digital camera (Canon PowerShot A620). The following description refers to the situation at the time of inspection. Alive specimens were collected in vials and brought to the laboratory for taking measurements and pictures under stereomicroscope, and for identification by means of specific keys.

\section{RESULTS}

The following is a description of the signs of insect presence discovered during the inspection, together with the identification of the causative agents when alive specimens were found. Tab. 1 shows where the signs were detected in the mosque and its surroundings, and their extent.

Big round holes (3-5 $\mathrm{mm} \varnothing$ ): in wood elements, mostly on the beams, ranging from a few dozens to a few hundred on each beam. They represent either entrance holes of adult females or the exit holes of newly emerged false powderpost beetles. Alive specimens collected from opened beams were identified as Bostrychoplites zycheli Marseul (Coleoptera, Bostrychidae).

Small round holes (1-2 $\mathrm{mm} \varnothing)$ : in wood elements, from a few dozens/golette to a few hundred/beam. They represent exit holes of newly emerged true powderpost beetles. Alive specimens from opened beams/golettes were identified as Lyctus africanus Lesne (Coleoptera, Lyctidae).

Big irregular holes and corresponding galleries (7-12 $\mathrm{mm} \quad$ ø): only in some of the beams exposed to open air, along the courts. They represent the nests of some local carpenter bee (Hymenoptera, Apidae, Xylocopinae), which were seen actively flying around the beams, although not catched.

Partially/totally destroyed beams or poles: almost all discarded beams (those removed during restoration operations) and the beams inside the minaret were almost completely destroyed. The type of damage and the dark "replacement wood" inside indicate high termite activity. In the big sandy court, all the wooden poles were seriously attacked by termites, and alive specimens found inside were later identified as Amitermes evuncifer Silvestri (Isoptera, Termitidae, Termitinae). 


\begin{tabular}{|c|c|c|c|c|c|c|c|c|}
\hline Location & Element & $\begin{array}{l}\text { Big } \\
\text { round } \\
\text { holes in } \\
\text { wood }\end{array}$ & $\begin{array}{l}\text { Small } \\
\text { round } \\
\text { holes in } \\
\text { wood }\end{array}$ & $\begin{array}{c}\text { Wood } \\
\text { destruction }\end{array}$ & $\begin{array}{c}\text { Mud } \\
\text { tubes/ } \\
\text { coverings }\end{array}$ & $\begin{array}{c}\text { Dark } \\
\text { galleries } \\
\text { inside } \\
\text { walls }\end{array}$ & $\begin{array}{l}\text { Mud } \\
\text { nests }\end{array}$ & $\begin{array}{c}\text { Small } \\
\text { holes in } \\
\text { walls }\end{array}$ \\
\hline \multirow{2}{*}{$\begin{array}{c}\text { Mosque } \\
\text { roof }\end{array}$} & \multirow{2}{*}{ Golettes } & $\mathrm{AR}-$ & $\mathrm{AR}+$ & $\mathrm{AR}-$ & $\mathrm{AR}-$ & \multirow[b]{2}{*}{-} & $\mathrm{AR}+$ & \multirow{2}{*}{-} \\
\hline & & NR - & $\mathrm{NR}++$ & NR n.d. & NR n.d. & & $\mathrm{NR}+$ & \\
\hline \multirow{2}{*}{$\begin{array}{l}\text { Mosque } \\
\text { roof }\end{array}$} & \multirow{2}{*}{ Beams } & $\mathrm{AR}+$ & $\mathrm{AR}+$ & $\mathrm{AR}+$ & $\mathrm{AR}+$ & \multirow[b]{2}{*}{-} & $\mathrm{AR}+$ & \multirow[b]{2}{*}{-} \\
\hline & & $\mathrm{NR}++$ & $\mathrm{NR}+++$ & $\mathrm{NR}+++$ & $\mathrm{NR}+++$ & & $\mathrm{NR}+$ & \\
\hline \multirow{2}{*}{ Mosque } & \multirow{2}{*}{ Architraves } & $\mathrm{AR}+$ & $\mathrm{AR}+$ & $\mathrm{AR}+$ & $\mathrm{AR}+$ & \multirow[b]{2}{*}{-} & $\mathrm{AR}+$ & \multirow[b]{2}{*}{-} \\
\hline & & $\mathrm{NR}++$ & $\mathrm{NR}+++$ & $\mathrm{NR}+++$ & $\mathrm{NR}+++$ & & $\mathrm{NR}+$ & \\
\hline \multirow{3}{*}{ Mosque } & \multirow{3}{*}{$\begin{array}{c}\text { Walls and } \\
\text { pillars }\end{array}$} & \multirow{3}{*}{-} & \multirow{3}{*}{-} & \multirow{3}{*}{-} & \multirow{3}{*}{-} & $\mathrm{AR}-$ & $\mathrm{AR}+$ & $\mathrm{AR}-$ \\
\hline & & & & & & UR++ & UR+ & UR++ \\
\hline & & & & & & NR n.d. & $\mathrm{NR}+$ & NR n.d \\
\hline Mosque & $\begin{array}{l}\text { Decor } \\
\text { panels }\end{array}$ & - & - & - & - & UR++ & UR+ & UR++ \\
\hline \multirow{3}{*}{ Mosque } & \multirow{3}{*}{ Doors } & $\mathrm{AR}-$ & $\mathrm{AR}-$ & $\mathrm{AR}-$ & $\mathrm{AR}++$ & & & \\
\hline & & UR - & UR - & UR - & UR - & - & - & - \\
\hline & & NR - & NR - & NR - & $\mathrm{NR}+$ & & & \\
\hline Mosque & Torons & NR - & NR - & $\mathrm{NR}+$ & $\mathrm{NR}+$ & - & - & - \\
\hline $\begin{array}{c}\text { Mosque } \\
\text { big sandy } \\
\text { court }\end{array}$ & $\begin{array}{l}\text { Wood poles } \\
\text { in the sand }\end{array}$ & - & - & $+++\sqrt{ }$ & ++ & - & - & - \\
\hline $\begin{array}{l}\text { Mosque } \\
\text { small } \\
\text { courts }\end{array}$ & $\begin{array}{c}\text { Beams } \\
\text { heaps, wood } \\
\text { boards }\end{array}$ & ++ & + & + & ++ & - & - & - \\
\hline $\begin{array}{l}\text { Mosque } \\
\text { minaret }\end{array}$ & Beams & +++ & +++ & +++ & ++ & - & + & - \\
\hline $\begin{array}{c}\text { Storage } \\
\text { area }\end{array}$ & Beams & $+++\sqrt{ }$ & $+++\sqrt{ }$ & +++ & + & - & - & - \\
\hline $\begin{array}{c}\text { Storage } \\
\text { area }\end{array}$ & Golettes & - & $+++\sqrt{ }$ & - & - & - & - & - \\
\hline $\begin{array}{c}\text { Outer } \\
\text { perimeter } \\
\text { streets }\end{array}$ & $\begin{array}{c}\text { Beams } \\
\text { heaps, wood } \\
\text { boards }\end{array}$ & +++ & +++ & +++ & ++ & - & - & - \\
\hline Private & Roof beams & +++ & +++ & ++ & +++ & & & \\
\hline houses & Wood poles & +++ & +++ & +++ & ++ & - & - & - \\
\hline
\end{tabular}

Tab. 1 - Signs of insect presence inside the mosque complex and its surroundings (AR= area already restored, $\mathrm{UR}=$ area under restoration, $\mathrm{NR}=$ area not restored; extent of damage: $-=$ absent, $+=$ small, $++=$ medium, $+++=$ high, n.d. $=$ not detectable, $\sqrt{ }=$ alive insects detected).

Mud tubes - mud coverings: found over roof beams, door architraves and other wood elements; inside private houses there were mud tubes up to $300 \mathrm{~mm}$ long hanging from the roof beams. They clearly indicate termite activity as they are typically made by termites as shelter structures during their foraging activities using saliva, excrements and soil. 
Dark galleries: discovered inside walls and decorated panels in the area under restoration, where the outer layers had been removed. Although no living insects were detected, these structures are likely to represent galleries performed by the termites coming from the ground, digging their way between the clay-straw layer and the yellow plaster layer to reach the roof beams. The dark colour of these galleries is due to the fact that usually termites, in order to prevent desiccation, line their galleries with mud/nest material, mixed with saliva and faeces.

Mud nests (50-100 $\mathrm{mm}$ long, 20-50 mm wide): frequently found inside the mosque, attached to the walls or to the beams. While inspecting, no living insects were ever seen around them. They represent "paedotrophic nests" built by adult females of some predator Hymenopterans (Sphecidae) with mud collected from the surroundings and saliva, to provide shelter and food for their larvae.

Small holes in the outer coverings (1-2 mm ø): detected in groups of 20-40 on some pillars and decorated panels. Although no living insects were ever detected, they could have been performed by some kind of local "plasterer bees" (Hymenoptera, Colletidae).

\section{DISCUSSION AND CONCLUSIONS}

From the evidence obtained during the inspection, the most serious problem for the Djingarey Ber mosque was represented by termites as structural pests of all wooden elements. Although presence of other species is not excluded, the one found inside the buried wood poles is A. evuncifer, a wood feeding termite common in West Africa, known to be a serious pest of buildings and wooden structures (Omo-Malaka \& Leuthold, 1986), that usually builds mounds in forests while in savannah is either subterranean or nesting in logs (Wood et al., 1980). Unfortunately the architecture and the materials used in this mosque are particularly favourable for termites: abundance of food sources (beams, golettes, rice straw inside walls) and walls/pillars directly in touch with the ground, whose structure allow termites to reach the food source on the roof using the "dark galleries" system, well sheltered inside the walls. Moreover, abundance of wood elements both inside the Mosque complex and in its immediate surroundings provides constant food supply for already established colonies and may attract new ones. Xylophagous beetles also represent a serious threat to the mosque and the high numbers of holes observed in the beams even in the recently restored area possibly indicates considerable structural damages to the affected elements. Lesne (1896) reports that B. zycheli was found in Timbuktu developing in palm wood and is well known as a pest of timber in service, just like L. africanus, endemic in the Oriental-African bioregions and presently worldwide distributed in all inter-tropical regions with dry climate (Walker, 2005).

From this survey it emerged also that termites, with their dark galleries inside the 
wall coverings, could represent a serious damage for the precious decorated panels found on some of the pillars, together with the small holes probably dug by local plasterer bees. Mud nests found all over inside the mosque could be considered just as a purely aesthetic damage.

Suggestions for a sustainable integrated management strategy aiming at reduction and prevention of attacks from wood pests include: a) wood treatment of all elements of the mosque complex and possibly also its surroundings using borate compounds which provide long-lasting efficacy against wood pests (Gentz \& Grace, 2006) and are relatively safe for mammals and the environment (Currie, 1996), b) removal of any non-treated wood/cellulosic material from the mosque and its surroundings to prevent re-infestation; c) in order the reduce wood pests in the mosque as well as inside private houses, it would be extremely useful to activate a basic education program on essential elements of wood protection, such as the prohibition to recycle old/infested wood, the basics of xylophagous insects biology and the use of borates instead of residual insecticides.

\section{ACKNOWLEDGEMENTS}

The authors are grateful to Dr. Souleymane Konate, Universite d'Abobo-Adjame (Abidjan, Côte d'Ivoire) for termite species determination.

\section{REFERENCES}

CurRIE W.E., 1996 - The Environmental Advantages of Using Diffusible Preservatives. In: Second International Conference on Wood Protection with Diffusible Preservatives and Pesticides, Ed. by Williams L.H., pp 38-41. Forest Products Society, Madison, WI.

Gentz M.C., Grace J.K., 2006 - A review of boron toxicity in insects with an emphasis on termites. J. Agr. Urban Entomol., 23: 201-207.

Lesne P., 1896 - Revision des coléoptères de la famille des Bostrychides. Société Entomologique de France, Paris, 65.

Omo MalaKa S.L., Leuthold R.H., 1986 - Mechanisms of recruitment for the retrieval of food in Amitermes evuncifer Silvestri (Isoptera: Termitidae: Termitinae). Insect Science and its Application, 7 (6): 707-721.

Walker K., 2005 - Powderpost beetle (Lyctus africanus). Pest and Diseases Image Library. Updated on 9/2/2011 3:33 PM Available online: PaDIL - http://www.padil.gov.au

Wood T.G., Sмith R.W., Johnson R.A., Komolafe P.O., 1980 - Termite damage and crop loss studies in Nigeria - Pre-harvest losses to yams due to termites and other soil pests. Tropical Pest Management, 26: 355-370. 
Lara Maistrello, Dip. Scienze Agrarie e degli Alimenti, Univ. di Modena e Reggio Emilia, Via G. Amendola 2, I-42122 Reggio Emilia, Italy.

E-mail: lara.maistrello@unimore.it

Josephine D’Ilario, Aga Khan Trust for Culture, 1-3 Avenue de la Paix, 1202 Geneva, Switzerland.

E-mail: josephine.dilario@akdn.org

Gautier Bicheron, Aga Khan Trust for Culture, 1-3 Avenue de la Paix, 1202 Geneva, Switzerland.

E-mail: bicheron.gautier@free.fr

Christophe Bouleau, Aga Khan Trust for Culture, 1-3 Avenue de la Paix, 1202 Geneva, Switzerland.

E-mail: christophe.bouleau@akdn.org 